\title{
Template-free Synthesis of Mesoporous Silica with High Specific Surface Area from Natural Halloysite and Its Application in Methylene Blue Adsorption
}

\author{
CHEN Meng-Qiu ${ }^{1}$, CHEN Yun ${ }^{2}$, SHU Zhu ${ }^{2}$, WANG Yu ${ }^{1}$, WU Hong-Juan ${ }^{1}$, GUO Li-Min ${ }^{1}$
}

(1. School of Environmental Science and Technology, Huazhong University of Science and Technology, Wuhan 430074, China; 2. Engineering Research Center of Nano-Geomaterials of Ministry of Education, Faculty of Materials Science and Chemistry, China University of Geosciences, Wuhan 430074, China)

\begin{abstract}
Avoiding the use of templates and employing natural minerals as raw materials could promote the cost-efficient preparation of mesoporous materials. This work demonstrated a template-free route to process natural halloysite into mesoporous silica with high specific surface area (SSA) up to $767 \mathrm{~m}^{2} / \mathrm{g}$ and pore size of about $5 \mathrm{~nm}$. The halloysite was successively calcined, alkali-treated and acid-treated. The transformation of calcined halloysite into crystalline sodium aluminosilicate (zeolite LTA) by longtime alkali-treating, was found to be the key for obtaining high-SSA mesoporous silica in the final acid treatment. The optimized mesoporous silica showed a monolayer adsorption capacity as high as $741 \mathrm{mg} / \mathrm{g}$ for methylene blue, suggesting its great potential in adsorption applications.
\end{abstract}

Key words: halloysite; mesoporous silica; template-free; zeolite; adsorption

Mesoporous materials are featured by the moderate pore size of 2-50 nm and large specific surface area, attracting great attention in applications such as adsorption, catalysis and separation ${ }^{[1-2]}$. Templating is the most prevalent strategy for preparing mesoporous materials but suffers from extremely costly templates ${ }^{[3-4]}$. Clay minerals are cheap on account of their abundant reserves in nature. It would be cost-efficient to prepare mesoporous materials from natural clay minerals via a template-free route. Halloysite is a typical clay mineral with a structural formula of $\mathrm{Al}_{2}(\mathrm{OH})_{4} \mathrm{Si}_{2} \mathrm{O}_{5} \cdot n \mathrm{H}_{2} \mathrm{O}$ and is distinctive for the tubular morphology ${ }^{[5]}$. The nanotube wall of halloysite consists of curved layers of crystalline aluminosilicate, and each layer unit is composed of a cornershared tetrahedral $\left[\mathrm{SiO}_{4}\right]$ sheet stacked with an edgeshared octahedral $\left[\mathrm{AlO}_{6}\right]^{[6]}$.

Selective etching chemistry is feasible in preparing mesoporous materials from halloysite. For example, Abdullayev, et $a l^{[7]}$ and Zhang, et $a l^{[8]}$ treated halloysite with sulphuric acid to etch the aluminum oxide component, and obtained the nanoporous silica nanotube with specific surface area (SSA) of $250 \mathrm{~m}^{2} / \mathrm{g}$ and $267 \mathrm{~m}^{2} / \mathrm{g}$, respectively. Shu, et $a l^{[9]}$ found that pre-calcining halloysite could activate the tubewall framework, and then, acid-etching resulted in mesoporous silica nanotube with enlarged SSA of $415 \mathrm{~m}^{2} / \mathrm{g}$. In order to further improve $\mathrm{SSA}$, Shu, et al ${ }^{[10]}$ introduced a short-term $\mathrm{NaOH}$ treat- ment on the pre-calcined halloysite, and then etched it with acid, producing mesoporous silica nanotubes with SSA as high as $608 \mathrm{~m}^{2} / \mathrm{g}$. Nevertheless, the SSA is still limited compared to those of the mesoporous silica fabricated by the traditional template methods $\left(700 \mathrm{~m}^{2} / \mathrm{g}\right.$ $1000 \mathrm{~m}^{2} / \mathrm{g}$ ) for FDU- ${ }^{[11]}$, SBA- $15^{[12]}$, KIT- $6^{[13]}$. Thus, it is still of urgency to develop new processes for preparing halloysite-derived mesoporous silica with further improved SSA.

In this work, the authors demonstrated that, a longterm alkali hydrothermal treatment coupled with the subsequent acid treatment, could process the calcined halloysite into mesoporous silica with further enlarged SSA up to $767 \mathrm{~m}^{2} / \mathrm{g}$. The effects of alkali treatments on the composition, morphology and porosity characteristics of halloysite-derived mesoporous silica were investigated and the mechanism of the evolution of mesoporosity was revealed. The adsorption behavior toward methylene blue (MB) of the mesoporous silica with optimized SSA was also investigated.

\section{Experimental}

\subsection{Preparation of mesoporous silica from halloysite \\ Halloysite, purchased from Danjiangkou Shunhe Clay}



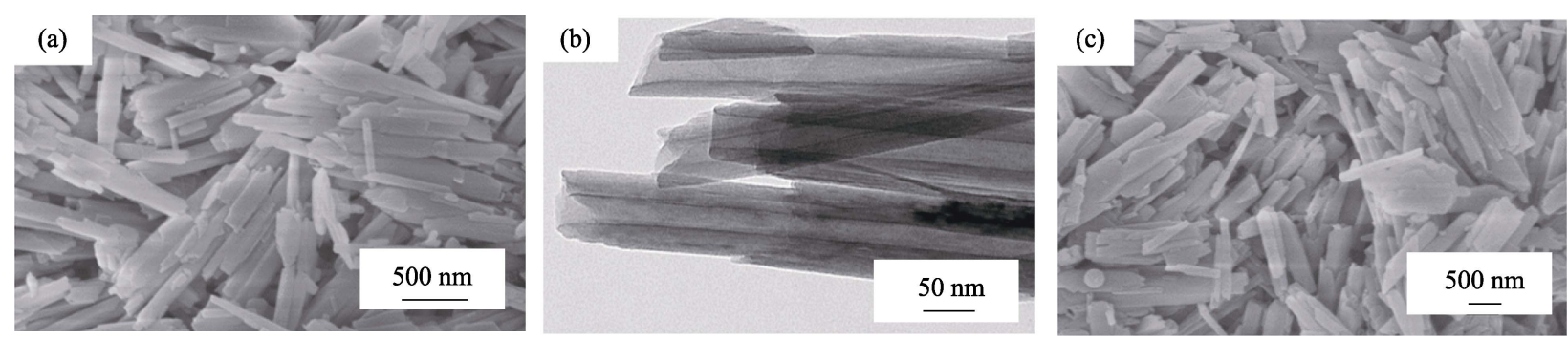

Fig. 1 SEM image (a) and TEM image (b) of halloysite, and SEM image (c) of the calcined halloysite

Co, Ltd., was calcined at $850^{\circ} \mathrm{C}$ for $4 \mathrm{~h}$. Then $7 \mathrm{~g}$ of calcined halloysite was magnetically stirred with $\mathrm{NaOH}$ aqueous solution $(140 \mathrm{~mL}, 4 \mathrm{~mol} / \mathrm{L})$ in a sealed Teflon vessel at $80^{\circ} \mathrm{C}$ for controlled time periods $(0.5,1,2,4$ and $6 \mathrm{~h}$ ), then filtered, purified with deionized water and dried at $110^{\circ} \mathrm{C}$. Afterwards, $5 \mathrm{~g}$ of the dried solid reacted with $\mathrm{HCl}$ aqueous solution $(100 \mathrm{~mL}, 5 \mathrm{~mol} / \mathrm{L})$ at $80^{\circ} \mathrm{C}$ for $6 \mathrm{~h}$ in a sealed glass bottle, then filtered, washed with deionized water and dried at $110^{\circ} \mathrm{C}$, becoming mesoporous silica product. The alkali-treated pre-calcinedhalloysite is named as $\mathrm{NaOH}-x$, where $x$ represents the alkali treating time. Correspondingly, the final acidetched product is named as $\mathrm{NaOH}-x-\mathrm{HCl}$.

\subsection{Dye adsorption test}

$20 \mathrm{mg}$ of $\mathrm{NaOH}-6 \mathrm{~h}-\mathrm{HCl}$ was added into $20 \mathrm{~mL} \mathrm{MB}$ solution in a $40 \mathrm{~mL}$ sealed glass vessel. The vessel was placed in a water-bath shaker at $170 \mathrm{r} / \mathrm{min}$ for $24 \mathrm{~h}$ at $25^{\circ} \mathrm{C}$ to achieve equilibrium state. The suspension was strained by $0.22 \mu \mathrm{m}$ cellulose filter and the transudate was determined by a UV-Vis spectrophotometer (V1600PC, MAPADA, China) at $664 \mathrm{~nm}$. The adsorption quantity $\left(Q_{\mathrm{e}}\right)$ at equilibrium was calculated by the follow equation:

$$
Q_{e}=\frac{\left(C_{0}-C_{\mathrm{e}}\right) V}{M}
$$

Where $C_{0}$ and $C_{\mathrm{e}}(\mathrm{mg} / \mathrm{L})$ are the initial and equilibrium concentrations of $\mathrm{MB}$ in solution, respectively, $V(\mathrm{~L})$ is the solution volume, and $M(\mathrm{~g})$ is the adsorbent dosage.

The effect of solution $\mathrm{pH}$ on adsorption efficiency was investigated firstly. The initial MB concentration was fixed at $400 \mathrm{mg} / \mathrm{L}$ and $\mathrm{pH}$ was adjusted from 2 to 12 by $\mathrm{HCl}$ and $\mathrm{NaOH}$ solutions. In the subsequent adsorption isotherm study, a constant $\mathrm{pH}$ of 8 was employed and the initial MB concentration was set to $150,200,300,500$, 700 and $1000 \mathrm{mg} / \mathrm{L}$. The adsorption isotherms were evaluated by three classical adsorption isotherm models: Langmuir, Freundlich, and Redlich and Peterson, the details of which are presented in the Supporting Information.

\subsection{Characterizations}

Chemical compositions were analyzed by PANalytical B.V. AXIOSmAX X-ray fluorescence (XRF) spectrome- try. X-ray powder diffraction (XRD) patterns were recorded by a Bruker AXS D8-Focus diffractometer. Field emission scanning electron microscopy (SEM) analysis was performed on a Hitachi SU8010 electron microscope. Field emission transmission electron microscopy (TEM) analysis was conducted on a JEOL 200CX electron microscope. $\mathrm{N}_{2}$ adsorption/desorption isotherms at $77 \mathrm{~K}$ were measured using a Micromeritics TriStar 3020 porosimeter. Specific surface area (SSA) was calculated by the Brunauer-Emmett-Teller (BET) method. Pore size distributions were analyzed by the Barrett-Joyner-Halenda (BJH) method.

\section{Results and discussion}

\subsection{Halloysite and calcined counterpart}

Halloysite shows the distinctive nanotube shape (Fig. 1(a) and (b)). XRD patterns (Fig. 2) reveal that raw halloysite is composed of $0.7 \mathrm{~nm}$ halloysite (PDF 29-487) as well as traces of quartz impurity (PDF 46-1045). XRF data (Table 1) indicates that halloysite are composed of silica and alumina, and the $\mathrm{Si} / \mathrm{Al}$ molar ratio $(1.03: 1)$ is consistent with the theoretical value $(1: 1)$. The calcined halloysite retains the nanotube shape (Fig. 1(c)), while the crystalline $0.7 \mathrm{~nm}$ halloysite transforms into the amorphous phase (Fig. 2). The transformation can be

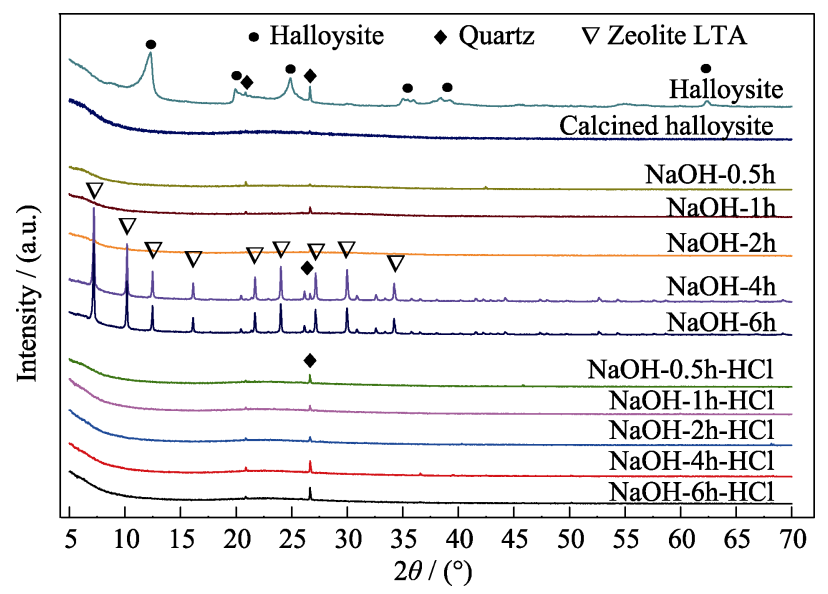

Fig. 2 XRD patterns of halloysite, calcined halloyiste, alkalitreated pre-calcinedhalloysite $(\mathrm{NaOH}-0.5 / 1 / 2 / 4 / 6 \mathrm{~h})$, and final acid-etched samples $(\mathrm{NaOH}-0.5 / 1 / 2 / 4 / 6 \mathrm{~h}-\mathrm{HCl})$ 
Table 1 XRF results of halloysite and calcined halloysite (wt\%)

\begin{tabular}{cccccccccccc}
\hline & $\mathrm{Si} / \mathrm{Al}^{\mathrm{a}}$ & $\mathrm{SiO}_{2}$ & $\mathrm{Al}_{2} \mathrm{O}_{3}$ & $\mathrm{Fe}_{2} \mathrm{O}_{3}$ & $\mathrm{MgO}$ & $\mathrm{CaO}$ & $\mathrm{Na}_{2} \mathrm{O}$ & $\mathrm{K}_{2} \mathrm{O}$ & $\mathrm{Others}^{2} \mathrm{LOI}^{\mathrm{b}}$ \\
\hline Halloysite & 1.03 & 45.2 & 37.2 & 0.305 & 0.008 & 0.738 & 0.022 & 0.057 & 1.35 & 15.1 \\
Calcined halloysite & 1.03 & 52.8 & 43.5 & 0.356 & 0.009 & 0.862 & 0.026 & 0.067 & 1.58 & 0.8 \\
\hline
\end{tabular}

${ }^{\mathrm{a}} \mathrm{Si} / \mathrm{Al}$ : the molar ratio of $\mathrm{Si}$ to Al. ${ }^{\mathrm{b}} \mathrm{LOI}$ : loss on ignition.

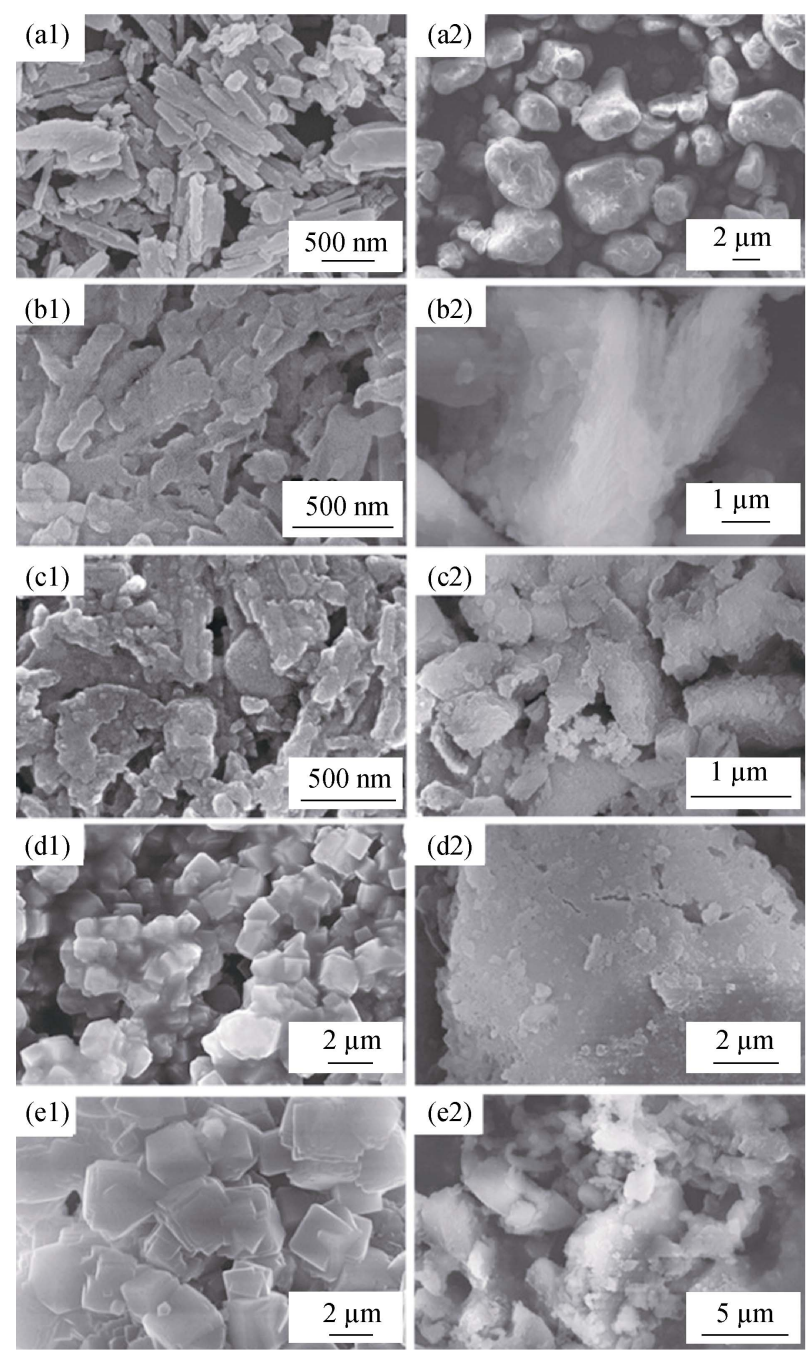

Fig. 3 SEM images of the alkali-treated pre-calcined halloysite and the final acid-etched samples

Alkali-treated pre-calcined halloysite: (a1) NaOH-0.5h; (b1) NaOH-1h; (c1) NaOH-2h; (d1) NaOH-4h; (e1) NaOH-6h

Final acid-etched samples: (a2) NaOH-0.5h-HCl; (b2) NaOH-1h-HCl; (c2) NaOH-2h-HCl; (d2) NaOH-4h-HCl; (e2) NaOH-6h-HCl

explicated via the well-known dehydroxylation process (Reaction (1) $)^{[5]}$, during which crystalline phase is thermalactivated into amorphous Si-O-Al network ${ }^{[14]}$.

$$
\mathrm{Al}_{2} \mathrm{O}_{3} \cdot 2 \mathrm{SiO}_{2} \cdot 2 \mathrm{H}_{2} \mathrm{O} \rightarrow \mathrm{Al}_{2} \mathrm{O}_{3} \cdot 2 \mathrm{SiO}_{2}+2 \mathrm{H}_{2} \mathrm{O} \text { (2) }
$$

\subsection{Alkali treatment of the pre-calcined hal- loysite}

After $0.5 \mathrm{~h}$ of alkali treatment, the calcined halloysite generally kept the tubular shape (Fig. 3(a1), SEM). When the treatment extends to $1 \mathrm{~h}$ and $2 \mathrm{~h}$, the alkali-treated sample gradually lost the tubular morphology (Fig. 3(b1) and (c1)). Moreover, they become microscale granules after $4 \mathrm{~h}$ or longer treatment (Fig. 3(d1) and (e1)). XRD (Fig. 2) and EDS (Table 2) results indicated that, the samples alkali-treated for less than $2 \mathrm{~h}$ are amorphous sodium aluminumsiliate. Beyond $4 \mathrm{~h}$, the sample became crystalline zeolite LTA (PDF 73-2340), which is a type of sodium aluminosilicate crystal. The Si-O-Al network of calcined halloysite is supposed to be etched by concentrated $\mathrm{OH}^{-}$and react with $\mathrm{Na}^{+}$to form new sodium aluminosilicate framework during alkali- hydrothermal treatment ${ }^{[10]}$. The long-enough treatment (above $4 \mathrm{~h}$ ) leaded to the formation of zeolite LTA crystals.

\subsection{Acid-etching of the alkali-treated pre- calcined halloysite}

$\mathrm{An} \mathrm{HCl}$ treatment was implemented on the alkalitreated pre-calcined halloysite $(\mathrm{NaOH}-0.5 / 1 / 2 / 4 / 6 \mathrm{~h})$. SEM images (Fig. 3) showed that the acid-treated samples are irregular microscale granules, and wormlike nanopores are evenly distributed in the granules (Fig. 4, TEM). All the acid-treated samples are amorphous (Fig. 2) and composed of mainly $\mathrm{SiO}_{2}$ (above $95 \%$ ) and traces of $\mathrm{Al}$

Table 2 EDS data of the alkali-treated samples and their acid-treated counterparts.

\begin{tabular}{ccccc}
\hline & $\mathrm{Si}$ & $\mathrm{Al}$ & $\mathrm{Na}$ & $\mathrm{O}$ \\
\hline $\mathrm{NaOH}-0.5 \mathrm{~h}$ & 18.39 & 16.79 & 1.93 & 62.91 \\
$\mathrm{NaOH}-1 \mathrm{~h}$ & 20.92 & 15.16 & 6.50 & 57.41 \\
$\mathrm{NaOH}-2 \mathrm{~h}$ & 20.06 & 15.25 & 7.94 & 56.71 \\
$\mathrm{NaOH}-4 \mathrm{~h}$ & 19.23 & 15.08 & 9.76 & 55.88 \\
$\mathrm{NaOH}-6 \mathrm{~h}$ & 20.34 & 13.70 & 9.85 & 56.05 \\
$\mathrm{NaOH}-0.5 \mathrm{~h}-\mathrm{HCl}$ & 32.37 & 0.81 & 0.39 & 66.43 \\
$\mathrm{NaOH}-1 \mathrm{~h}-\mathrm{HCl}$ & 32.43 & 0.83 & 0.43 & 66.31 \\
$\mathrm{NaOH}-2 \mathrm{~h}-\mathrm{HCl}$ & 32.71 & 0.67 & 0.14 & 66.49 \\
$\mathrm{NaOH}-4 \mathrm{~h}-\mathrm{HCl}$ & 32.37 & 0.90 & 0.42 & 66.31 \\
$\mathrm{NaOH}-6 \mathrm{~h}-\mathrm{HCl}$ & 32.61 & 0.59 & 0.48 & 66.33 \\
\hline
\end{tabular}

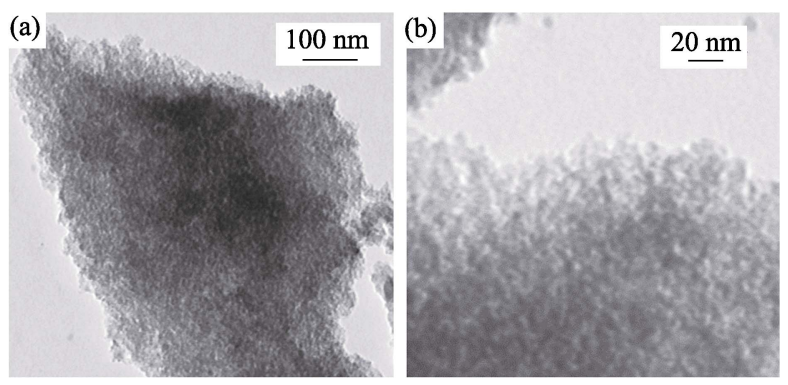

Fig. 4 TEM images of $\mathrm{NaOH}-6 \mathrm{~h}-\mathrm{HCl}$ (a) and magnified one (b) 
Table 3 Porosity parameters of the acid-etched samples

\begin{tabular}{ccccccc}
\hline Samples & $S S A /\left(\mathrm{m}^{2} \cdot \mathrm{g}^{-1}\right)$ & $S_{\text {micro }} /\left(\mathrm{m}^{2} \cdot \mathrm{g}^{-1}\right)$ & $S_{\text {external }} /\left(\mathrm{m}^{2} \cdot \mathrm{g}^{-1}\right)$ & $V_{\mathrm{t}} /\left(\mathrm{cm}^{3} \cdot \mathrm{g}^{-1}\right)$ & $V_{\text {micro }} /\left(\mathrm{cm}^{3} \cdot \mathrm{g}^{-1}\right)$ & $V_{\text {meso }} /\left(\mathrm{cm}^{3} \cdot \mathrm{g}^{-1}\right)$ \\
\hline $\mathrm{NaOH}-0.5 \mathrm{~h}-\mathrm{HCl}$ & 547 & 17.2 & 530 & 0.762 & 0.002 & 0.760 \\
$\mathrm{NaOH}-1 \mathrm{~h}-\mathrm{HCl}$ & 573 & 33.8 & 539 & 0.826 & 0.007 & 0.819 \\
$\mathrm{NaOH}-2 \mathrm{~h}-\mathrm{HCl}$ & 709 & 12.7 & 696 & 0.725 & 0 & 0.725 \\
$\mathrm{NaOH}-4 \mathrm{~h}-\mathrm{HCl}$ & 749 & 13.4 & 736 & 0.703 & 0 & 0.703 \\
$\mathrm{NaOH}-6 \mathrm{~h}-\mathrm{HCl}$ & 767 & 8.64 & 759 & 0.669 & 0 & 0.669 \\
\hline
\end{tabular}

and $\mathrm{Na}$ species (Table 2). The majority of $\mathrm{Al}-\mathrm{O}$ and $\mathrm{Na}-\mathrm{O}$ in the alkali-treated samples (amorphous or crystalline sodium aluminosilicate) is believed to be dissolved by acid, and the $\mathrm{Si}-\mathrm{O}$ component precipitated due to the acid environment. They formed hydrated $\mathrm{SiO}_{2}$ nanoparticles and aggregated into microscale granules containing inter- particle nanopores. The SSA of acid-etched samples (Table 3) reaches up to $767 \mathrm{~m}^{2} / \mathrm{g}$, which is much superior to those of the halloysite-derived nanoporous silica in literatures (below $\left.608 \mathrm{~m}^{2} / \mathrm{g}\right)^{[7-10,15]}$. The $\mathrm{N}_{2}$ adsorption- desorption isotherms (insert in Fig. 5) are typical Langmuir IV curves with $\mathrm{H}_{2}$ hysteresis loops, indicating that the nanopores are ink-bottle mesopores with pore sizes centralized around $5 \mathrm{~nm}$ (Fig. 5).

The alkali-treatment time has a significant impact on the porosity of final acid-treated samples. $\mathrm{NaOH}-0.5 \mathrm{~h}-$ $\mathrm{HCl}$, undergoing the shortest alkali-treatment, has the lowest SSA of $547 \mathrm{~m}^{2} / \mathrm{g}$. Prolonging alkali-treatment to $1 \mathrm{~h}$ and $2 \mathrm{~h}$ gradually enlargeed the SSA of acid-treated sample to $573 \mathrm{~m}^{2} / \mathrm{g}$ and $709 \mathrm{~m}^{2} / \mathrm{g}$. Further prolonged alkali-treatment of $4 \mathrm{~h}$ and $6 \mathrm{~h}$ results in SSA as high as $749 \mathrm{~m}^{2} / \mathrm{g}$ and $767 \mathrm{~m}^{2} / \mathrm{g}$, respectively. XRD results (Fig. 2) showed that, the prolonged alkali-treatment from $0.5 \mathrm{~h}$ to $4 \mathrm{~h}$ mainly contributes to the transformation of amorphous calcined-halloysite into crystalline zeolite LTA. Thus, the reorganization of Si-O-Al network of calcined halloysite into the sodium aluminosilicate framework of zeolite LTA by longtime alkali-treating, should be the key for obtaining high-SSA mesoporous silica in acid-treatment.

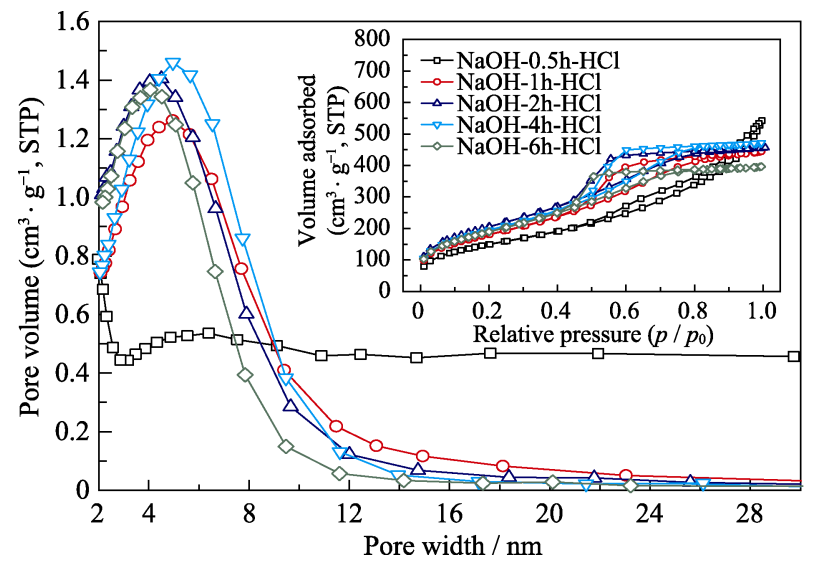

Fig. 5 BJH pore size distribution plots and $\mathrm{N}_{2}$ adsorptiondesorption isotherm (insert) of the final samples
It is supposed that the crystalline sodium aluminosilicate framework of zeolite LTA deconstructed in acid via sodium/ aluminum dissolving and became amorphous residual topologies of hydrated silica nanoparticles. Then, the intermediate hydrated silica nanoparticles bonded with each other through the dehydration condensation of silanol groups, and constructed irregular granules with inner mesopores, i.e. mesoporous silica with high SSA.

\subsection{Adsorption performance of the mesoporous} silica

The effect of solution $\mathrm{pH}$ on the $\mathrm{MB}$ adsorption efficiency of $\mathrm{NaOH}-6 \mathrm{~h}-\mathrm{HCl}$ was shown in the insert of Fig. 6. When the $\mathrm{pH}$ value raises from 2 to 8 , the $\mathrm{MB}$ removal efficiency increased from $61.3 \%$ to $95.9 \%$ and maintained above $95 \%$ at further elevated $\mathrm{pH}$. The superior adsorption efficiency at high $\mathrm{pH}$ values can be attributed to the increased negative charges on the adsorbent in alkali environment, which promotes the adsorption of the positively charged MB cations ${ }^{[16]}$. The $\mathrm{pH}$ of 8 was chosen for the subsequent adsorption isotherm study. Adsorption isotherms and non-linear fitting plots are presented in Fig. 6. Detailed parameters of three adsorption isotherm models are shown in Table S1. The fitting quality follows the order Redlich-Peterson $\left(R^{2}=0.991\right)>$ Langmuir $\left(R^{2}=0.986\right)>$ Freundlich $\left(R^{2}=0.932\right)$ in view of the $R^{2}$ value of three models. Thus, the MB adsorption is assumed to primarily occur by monolayer adsorption on heterogeneous surfaces with different intensity and

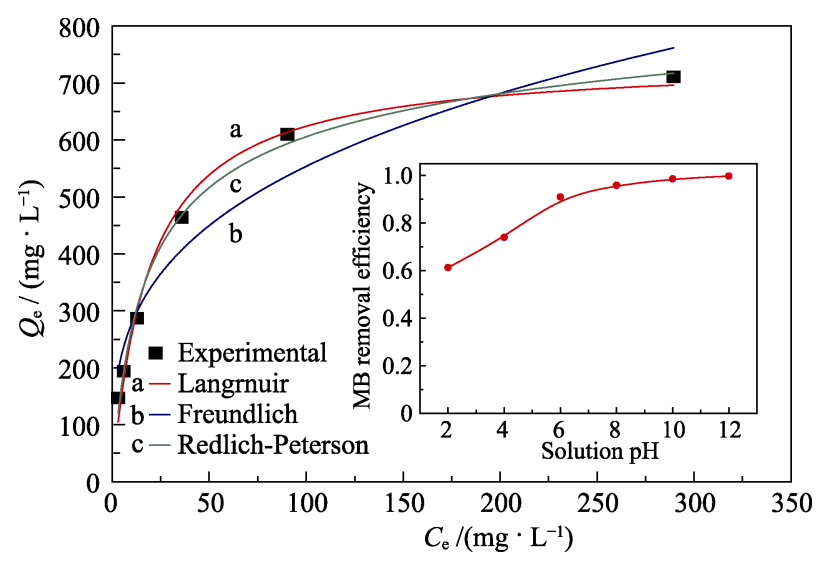

Fig. 6 Effect of solution $\mathrm{pH}$ on $\mathrm{MB}$ adsorption efficiency (insert), and Langmuir, Freundlich and Redlich-Peterson isotherms for $\mathrm{MB}$ adsorption on $\mathrm{NaOH}-6 \mathrm{~h}-\mathrm{HCl}$ 
Table 4 MB adsorption capacities of NaOH-6h- $\mathrm{HCl}$ and other excellent adsorbents

\begin{tabular}{ccccc}
\hline Adsorbent & $\mathrm{Q}_{\mathrm{m}} /\left(\mathrm{mg} \cdot \mathrm{g}^{-1}\right)$ & $\mathrm{SSA} /\left(\mathrm{m}^{2} \cdot \mathrm{g}^{-1}\right)$ & $\left(\mathrm{Q}_{\mathrm{m}} / \mathrm{SSA}\right) /\left(\mathrm{mg} \cdot \mathrm{m}^{-2}\right)$ & Ref. \\
\hline NaOH-6h-HCl & 741 & 767 & 0.966 & This work \\
Mesoporous silica nanotubes & 618 & 608 & 1.020 & {$[10]$} \\
Mesoporous silica nanotubes & 427 & 415 & 1.030 & {$[9]$} \\
Bamboo activated-carbon & 454 & 1896 & 0.240 & {$[18]$} \\
Mesoporous silica SBA-15 & 280 & 668 & 0.419 & {$[19]$} \\
Graphene & 154 & 295 & 0.522 & {$[20]$} \\
\hline
\end{tabular}

energy. The active energetic heterogeneity of mesoporous silica may result from the irregular pore shape, wide-distributed pore size, surface functional groups and impurities ${ }^{[17]}$. According to the Langmuir isotherm model, $\mathrm{NaOH}-6 \mathrm{~h}-\mathrm{HCl}$ has a monolayer MB adsorption capacity of $714 \mathrm{mg} / \mathrm{g}$, equivalent and even superior to the reported excellent adsorbents such as activated carbon ${ }^{[18]}$, ordered mesoporous silica ${ }^{[19]}$ and graphene ${ }^{[20]}$ (Table 4), indicating its promising perspective in adsorption applications.

\section{Conclusions}

A route of successive calcination, alkali treatment and acid treatment, was developed to process natural halloysite into mesoporous silica with SSA as high as $767 \mathrm{~m}^{2} / \mathrm{g}$ and pore size of about $5 \mathrm{~nm}$, which demonstrated an excellent monolayer MB adsorption capacity of $714 \mathrm{mg} / \mathrm{g}$ at $\mathrm{pH}=8$. The crystalline halloysite becomes amorphous aluminosilicate in calcination, then reacts with concentrated sodium hydroxide to form sodium aluminosilicate during alkali treatment, and finally decomposes into mesoporous silica due to the dissolving of sodium and aluminum components in acid treatment. The formation of crystalline sodium aluminosilicate (zeolite LTA) by longtime alkali-treatment, is the key to obtain high-SSA mesoporous silica in subsequent acid-treatment. This technique could be cost-efficient on account of the template-free feature and the particular use of natural mineral as the sole raw materials.

\section{Reference:}

[1] WAN Y, ZHAO D Y. On the controllable soft-templating approach to mesoporous silicates. Chem. Rev., 2007, 107(7): 2821-2860.

[2] WANG Y, YANG D, LI S, et al. Ru/hierarchical HZSM-5 zeolite as efficient bi-functional adsorbent/catalyst for bulky aromatic VOCs elimination. Microporous Mesoporous Mater., 2018, 258: $17-25$.

[3] REN Y, MA Z, BRUCE P G. Ordered mesoporous metal oxides: synthesis and applications. Chem. Soc. Rev., 2012, 41(14): 49094927.

[4] LI W, ZHAO D Y. An overview of the synthesis of ordered mesoporous materials. Chem. Commun., 2013, 49(10): 943-946.

[5] YUAN P, TAN D Y, ANNABI-BERGAYA F. Properties and appli- cations of halloysite nanotubes: recent research advances and future prospects. Appl. Clay Sci., 2015, 112-113: 75-93.

[6] LUN H L, OUYANG J, YANG H M. Enhancing dispersion of halloysite nanotubes via chemical modification. Phys. Chem. Miner., 2014, 41(4): 281-288.

[7] ABDULLAYEV E, JOSHI A, WEI W, et al. Enlargement of halloysite clay nanotube lumen by selective etching of aluminum oxide. ACS Nano, 2012, 6(8): 7216-7226.

[8] ZHANG A B, PAN L, ZHANG H Y, et al. Effects of acid treatment on the physico-chemical and pore characteristics of halloysite. Colloid Surf. A-Physicochem. Eng. Asp., 2012, 396: 182-188.

[9] SHU Z, CHEN Y, ZHOU J, et al. Nanoporous-walled silica and alumina nanotubes derived from halloysite: controllable preparation and their dye adsorption applications. Appl. Clay Sci., 2015, 112-113: 17-24.

[10] SHU Z, CHEN Y, ZHOU J, et al. Preparation of halloysite-derived mesoporous silica nanotube with enlarged specific surface area for enhanced dye adsorption. Appl. Clay Sci., 2016, 132: 114-121.

[11] DA SILVA L C C, INFANTE C M C, URIO R D, et al. Adsorption/ desorption of $\mathrm{Hg}(\mathrm{II})$ on FDU-1 silica and FDU-1 silica modified with humic acid. Sep. Sci. Technol., 2015, 50(7): 984-992.

[12] CHANDRASEKAR G, SON W J, AHN W S. Synthesis of mesoporous materials SBA-15 and CMK-3 from fly ash and their application for $\mathrm{CO}_{2}$ adsorption. J. Porous Mat., 2009, 16(5): 545-551.

[13] LI T T, SHU Z, ZHOU J, et al. Template-free synthesis of kaolin-based mesoporous silica with improved specific surface area by a novel approach. Appl. Clay Sci., 2015, 107: 182-187.

[14] OUYANG J, ZHOU Z, ZHANG Y, et al. High morphological stability and structural transition of halloysite (Hunan, China) in heat treatment. Appl. Clay Sci., 2014, 101: 16-22.

[15] JOO Y, SIM J H, JEON Y, et al. Opening and blocking the innerpores of halloysite. Chem. Commun., 2013, 49(40): 4519-4521.

[16] HARRIS R G, JOHNSON B B, WELLS J D. Studies on the adsorption of dyes to kaolinite. Clay Clay Min., 2006, 54(4): 435-448.

[17] BALATHANIGAIMANI M S, SHIM W G, PARK K H, et al. Effects of structural and surface energetic heterogeneity properties of novel corn grain-based activated carbons on dye adsorption. Micropor. Mesopor. Mat., 2009, 118(1/2/3): 232-238.

[18] HAMEED B H, DIN A T M, AHMAD A L. Adsorption of methylene blue onto bamboo-based activated carbon: kinetics and equilibrium studies. J. Hazard. Mater., 2007, 141(3): 819-825.

[19] DONG Y L, LU B, ZANG S Y, et al. Removal of methylene blue from coloured effluents by adsorption onto SBA-15. J. Chem. Technol. Biotechnol., 2011, 86(4): 616-619.

[20] LIU T, LI Y, DU Q, et al. Adsorption of methylene blue from aqueous solution by graphene. Colloid Surf. B-Biointerfaces, 2012, 90: 197-203. 


\title{
埃洛石原料无模板法制备高比表面积介孔氧化硅 及其在亚甲基蓝吸附中的应用
}

\author{
陈孟秋 ${ }^{1}$, 陈 云 $^{2}$, 舒 杼 $^{2}$, 王 钰 ${ }^{1}$, 邬红娟 ${ }^{1}$, 郭利民 ${ }^{1}$
}

(1. 华中科技大学 环境科学与工程学院, 武汉 430074; 2. 中国地质大学(武汉) 材料与化学学院, 武汉 430074 )

摘 要: 采用无模板法, 以天然的矿物原料制备介孔材料是一种经济有效的制备方法。本研究利用 “煅烧-沸石化一 酸处理” 工艺制备高比表面积的介孔氧化硅颗粒。研究发现, 通过长时间的碱处理将煅烧埃洛石转化为沸石, 随 后通过酸处理, 可制备出比表面积高达 $767 \mathrm{~m}^{2} / \mathrm{g}$ 的介孔氧化硅材料。该工艺机理为: $850^{\circ} \mathrm{C}$ 㷽烧使埃洛石转变为无 定型态的 Si-O-Al 网络结构, 煅烧埃洛石在长时间的水热碱处理过程中转化为结晶态的 LTA 沸石硅铝酸钠, 在随 后的强酸性环境下, 沸石的 Al-O 和 Na-O 成分被完全溶解, 而残余的 Si-O 纳米碎片在酸环境中相互聚合, 生成无 定形态的介孔氧化硅颗粒。本实验制备的介孔氧化硅比表面积高达 $767 \mathrm{~m}^{2} / \mathrm{g}$, 最可几孔径为 $5 \mathrm{~nm}$, 其亚甲基蓝平 衡吸附量可达 $741 \mathrm{mg} / \mathrm{g}$, 表明其在污染物吸附中具有良好的应用潜力。

关 键 词: 埃洛石; 介孔氧化硅; 无模板法; 沸石; 吸附 中图分类号: TQ174 文献标识码: A 


\title{
Template-free Synthesis of Mesoporous Silica with High Specific Surface Area from Natural Halloysite and Its Application in Methylene Blue Adsorption
}

\author{
CHEN Meng-Qiu ${ }^{1}$, CHEN Yun ${ }^{2}$, SHU Zhu ${ }^{2}$, WANG Yu ${ }^{1}$, WU Hong-Juan ${ }^{1}$, Guo Li-Min ${ }^{1}$ \\ (1. School of Environmental Science and Technology, Huazhong University of Science and Technology, Wuhan430074, China; \\ 2. Engineering Research Center of Nano-Geomaterials of Ministry of Education, Faculty of Materials Science and Chemistry, \\ China University of Geosciences, Wuhan430074, China)
}

The adsorption isotherms were evaluated by three classical adsorption isotherm models: Langmuir $^{[1]}$, Freundlich $^{[2]}$, and Redlich and Peterson ${ }^{[3]}$, which follow the equations (S1), (S2) and (S3), respectively.

$$
\text { Langmuir: } \quad Q_{e}=\frac{Q_{m} b C_{e}}{1+b C_{e}}
$$

Where $Q_{e}(\mathrm{mg} / \mathrm{g})$ is the quantity of adsorbed MB at equilibrium. $C_{\mathrm{e}}(\mathrm{mg} / \mathrm{L})$ is the equilibrium $\mathrm{MB}$ concentration in solution. $Q_{m}(\mathrm{mg} / \mathrm{g})$ is a constant which indicates the maximum monolayer adsorption capacity of adsorbent. $b$ is a constant corresponding to the affinity of adsorbent towards adsorbate, the increased value of $b$ suggesting stronger affinity. Langmuir isotherm model assumes that adsorption occurs on the homogenous surface and no interaction happens between the adsorbates on the plane of surface.

$$
\text { Freundilch: } \quad Q_{e}=K_{F} C_{e}^{1 / n}
$$

Where $K_{F}$ is a constant representing the amount of adsorbate in per unit of adsorbent. The slope $1 / n$, between 0 and 1 , represents the surface heterogeneity of the adsorbent, and the value of $1 / n$ closer to 0 implies the higher heterogeneity. Freundlich equation is an empirical equation and supposes the adsorption occurring on heterogeneous surfaces with different energy of adsorption.

$$
\text { Redlich-Peterson: } \quad Q_{e}=\frac{A C_{e}}{1+B C_{e}^{g}}
$$

The Redlich-Peterson isotherm model involves the
Table S1 Parameters of three adsorption isotherm models for MB adsorption on NaOH-6 h-HCl

\begin{tabular}{ccc}
\hline Isotherm models & Parameters & Value \\
\hline Langmuir & $Q_{\mathrm{m}} /\left(\mathrm{mg} \cdot \mathrm{g}^{-1}\right)$ & 741 \\
& $b /\left(\mathrm{mg} \cdot \mathrm{L}^{-1}\right)$ & 0.053 \\
& $R^{2}$ & 0.986 \\
Freundlich & $K_{\mathrm{F}}$ & 139 \\
& $1 / n$ & 0.300 \\
Redlich-Peterson & $R^{2}$ & 0.936 \\
& $g$ & 0.912 \\
& $\mathrm{~A} /\left(\mathrm{L} \cdot \mathrm{g}^{-1}\right)$ & 51.2 \\
& $\mathrm{~B} /\left(\mathrm{L} \cdot \mathrm{mg}^{-1}\right)$ & 0.111 \\
& $R^{2}$ & 0.991 \\
\hline
\end{tabular}

features of both Langmuir and Freundlich isotherm models. $A, B$, and $g$ are constants. $g$ indicates the tendency towards the Langmuir or Freundlich model. When $g=1$, the Redlich-Peterson model equals to the Langmuir model.

\section{References}

[1] LANGMUIR I. The constitution and fundamental properties of solids and liquids. J. Am. Chem. Soc., 1916, 38(11): 2221-2295.

[2] FREUNDLICH H M F. Over the adsorption in solution. J. Phys. Chem., 1906, 57: 385-470.

[3] REDLICH Q, PETERSON D L. A useful adsorption isotherm. J. Phy. Chem., 1959, 63(6): 1024. 